\title{
A CORREÇÃO DOS FIÉIS NÃO DEVOTOS NA CASTELA DOS SÉCULOS XIV E XV*
}

\author{
POR \\ LEANDRO ALVES TEODORO ${ }^{1}$ \\ Universidade Universidade Estadual de Campinas - UNICAMP \\ Universidade Estadual Paulista Júlio de Mesquita Filho \\ UNESP - Campus de Franca.
}

\begin{abstract}
RESUMO
A partir do início do século XIV, aumenta o espaço reservado em obras eclesiásticas produzidas em terras castelhano-leonesas, especialmente em constituições sinodais e tratados pastorais, para debater os limites da ação dos cristãos soberbos, a fim de fazê-los obedientes aos ensinamentos prescritos por confessores e bispos. Partindo de obras que ensinavam os curas de almas a admoestar o fiel pecador, o presente trabalho visa examinar como clérigos e religiosos da Coroa de Castela ajudaram a convencer homens e mulheres a naturalizar virtudes contrárias ao pecado mortal da soberba, sobretudo a humildade. Em outras palavras, o alvo deste estudo é analisar em que medida a prática da devoção dos fiéis leigos dependia, entre outras ações, de uma conduta obediente aos mandamentos e avessa aos pecados considerados derivados da soberba, como a rebeldia.
\end{abstract}

PALAVRAS-CHAVE: soberba; humildade; devoção; Coroa de Castela; séculos XIV e XV.

\section{THE CORRECTION OF THE NON-DEVOUT FAITHFUL IN FOURTEENTH AND FIFTEENTH CENTURY CASTILE}

\begin{abstract}
From the beginning of the fourteenth century, there is an increase in the amount of space assigned in ecclesiastical works produced in Castilian-Leonean lands, especially in synodic constitutions and pastoral treatises, to the subject of limiting the actions of churchgoers guilty of the sin of pride (superbia). The purpose being to reform these sinners and make them obedient to the teachings prescribed by confessors and bishops. Based on works that aimed to teach confessors to admonish the faithful sinner, this essay seeks to examine how ministers and clergymen in the kingdom of Castile helped to convince men and women to embrace the virtues contrary to the mortal sin of pride, especially humility. In other words, the aim of this study is to analyse to what extent the practice of devotion by lay churchgoers depended, among other things, on a behaviour of obedience to the commandments and aversion to sins considered to be derived from pride, such as insurgence.
\end{abstract}

KEY WORDS: pride (superbia); humility; devotion; kingdom of Castile; 14th and 15th centuries.

CÓMO CITAR ESTE ARTículo / CITATION: Teodoro, L. A. 2019. «A correção dos fiéis não devotos na Castela dos séculos XIV e XV》. Hispania Sacra 71, 144: 417-426. https://doi.org/10.3989/hs.2019.29

Recibido/Received 20-02-2018

Aceptado/Accepted 14-03-2019

\section{APRESENTAÇÃO: O ESPÍRITO INDEVOTO}

Nascido em 1350, em Valência, o dominicano Vicente Ferrer fez muito sucesso em Castela como missionário e

Este artigo foi elaborado no ámbito do projeto «O Ensino da fé cristã na Península Ibérica (séc. XIV e XV)» (PROCESSO FAPESP 2017/11111-7). O autor deste trabalho também é membro do Grupo Temático "Escritos sobre os novos mundos», sediado na Universidade Estadual Paulista (UNESP), campus Franca

1 leandroateodoro@uol.com.br / ORCID iD: https://orcid.org/0000-0002-5580-8838 pregador entre 1411 e 1412, ganhando destaque por cativar fiéis de diferentes dioceses e ensinar-lhes temas variados acerca dos dogmas da Igreja, dos rudimentos da doutrina cristã e da vinda do Anticristo. ${ }^{2}$ Quando estava na vila castelhana de Ayllón em setembro de 1411, esse religioso proferiu um sermão em que catalogou nove tipos de vidas

2 A respeito de um panorama geral dos temas abordados pelo referido religioso durante sua missão em Castela, ver Cátedra 1994. Ver também Baloup 2003 e Vidal Doval 2010. 
más, ${ }^{3}$ a fim de convencer homens e mulheres a repensar a sua conduta cotidiana. Dessa lista, uma das formas de vida repreendida por ele que nos interessa mais diretamente é aquela taxada de espírito indevoto (spiritualis indevotio). De acordo com o dominicano, o cristão que se enquadrava nessa designação tinha o hábito de sair das solenidades antes do término para conversar com outras pessoas do lado de fora da igreja. ${ }^{4}$ Dando sequência à sua prédica, elucida a mensagem do sermão a partir da paráfrase de conversas comumente assistidas nas portas das igrejas daquela época:

E vós, minhas filhas, perdoai-me se digo a verdade, que quando vindes à igreja ali falais com alguém, dizendo: - "Como vos vai, comadre? E como está meu compadre? Vai bem minha afilhada?". E outras coisas tais. E se vedes vir com alguma vestida de novo, lhe dizeis: "Oh, como está bem feita esta roupa! E quem a fez para vós? Que bom pano, de onde o tirastes?". -E ali na igreja falais estas coisas e outras piores. $E$ ainda, o que é pior, ali murmurais e detraís umas das outras com inveja, dizendo: "Vedes qual vem fulana! Não sabeis o que ela fez outro dia?". 5

Esse religioso denuncia, em diversos sermões dos anos de 1411 e 1412, a falta de compromisso dos fiéis cristãos para acompanhar as missas, confessar os pecados mortais e se conduzir pelos mandamentos da lei de Deus. Descrevendo diante de homens e mulheres exemplos como esse de cenas pecadoras, esse pregador destaca a necessidade de todo fiel refletir acerca de sua conduta dentro e fora da igreja, com a finalidade de que soubesse como professar a fé cristã para honrar corretamente com seus deveres. Afinal, um dos diferencias da recolha de sermões de Vicente Ferrer trata-se de sua riqueza de exempla em que a ação narrada é construída como suporte mnemotécnico; isto é, um recurso para despertar a atenção do publico e fazê-lo reter a lição preparada para aquela prédica (Cátedra 1994: 194).

O tema dos compromissos do fiel devoto e temente a Deus já havia sido explorado pouco tempo antes pelo religioso de origem aragonesa, o célebre franciscano Francisc Eiximenis, cuja obra também ecoou por Castela no século XV. No final do Trezentos, poucos anos antes de Vicente Ferrer se aventurar em sua missão em solo castelhano, Eiximenis havia produzido um tratado intitulado Llibre de les Dones ${ }^{6}$ com o objetivo de divulgar um rol de doutrinas

3 Eis a lista apresentada por Vicente Ferrer: 1) carnal conversaçión; 2) spiritualis indevoto; 3) crudelis inconpassio; 4) amaricabilis inpaciencia; 5) inplacabilis discordia; 6) tirannicalis presidençia; 7) usurpatio spiritualis; 8) fidey desertio; 9) blasfemia in Deum.

4 "La segunda manera de mala vida es spiritualis indevotio. Esto es quando la persona non ha devoçión spiritual en ninguna cosa que sea de Dios. Ca muchos sson que nunca oen misa conplida, ca vienen a la meytat e sálense ante que acaben fuera de la Ygleia a fablar follías e suziedades e otras muchas vanidades» (Ferrer 1994: 289).

5 «E vosotras, mis fijas, perdonadme si digo la verdat, que quando venides a la igleia allí fablades en uno, deziendo: - “¿Como vos va, comadre? ¿E cómo está mi conpadre? ¿Va ya bien a mi afijada?". E otras cosas tales. E si vedes venir a alguna vestida de nuevo, dezídesle - “O, cómo es bien fecha esta rropa! ¿E quién vos la fizo? ¡O, qué buen paño, e dónde lo sacastes?". E allí en la igleia fablades estas cosas e otras peores. E aun, lo que es peor, allí murmurades e detraedes unas de outras con enbidia, diçiendo: — “iVedes quál viene fulana! ¿Não sabedes lo que fizo este otro día?”» (Ferrer 1994: 289).

6 Uma das versões da obra Llibre de les Dones mais conhecidas é uma adaptação realizada por um anônimo chamado de P. Carmona. Essa destinado à formação das mulheres. ${ }^{7}$ Numa altura em que reservou espaço para abordar prédicas voltadas à formação cristã em geral, esse religioso assevera: «não somente aos religiosos é necessária a virtude da obediência, mas ainda a toda gente do mundo». ${ }^{8}$ Penetrando no campo do ordenamento dos valores e das condutas, Eiximenis defende que a obediência é um ato de entrega ao Criador, por corresponder à negação da própria vontade e dos impulsos que geravam os pecados mortais.

Essa parte do Llibre de les Dones e o referido sermão de Vicente Ferrer possuem um eixo em comum: a relação entre devoção e respeito a Deus. Mesmo que Ferrer, no referido sermão, não tenha dissertado diretamente sobre a obediência, o exemplo por ele mencionado das mulheres que conversavam na porta das igrejas servia para constranger os fiéis castelhanos e convencê-los a mostrar respeito ao seu Criador. Segundo o dominicano, a devoção era uma manifestação plena de obediência e deferência à Igreja e suas raízes. Em linhas gerais, as prédicas desses dois autores fortaleceram a pastoral cristã num período em que bispos e outros letrados da Igreja debatiam sobre a melhor maneira de punir fiéis tidos como rebeldes e ensinar a diferentes tipos de cristãos o valor da virtude da obediência. ${ }^{9}$ Conforme veremos, da primeira metade do século XIV até ao final do XV, não pararam de surgir recomendações e ensinamentos para os cristãos de Castela saberem como evitar a soberba e a escapar de qualquer ação que caracterizasse a falta de comprometimento em relação aos seus deveres religiosos.

\section{OBEDIÊNCIA E DEVOÇÃO}

No início do Trezentos, Martín Pérez terminava a elaboração do Libro de las confesiones, conhecido como um dos principais tratados pastorais que circulou pela Península Ibérica entre os séculos XIV e XV, especialmente pelos bispados da região centro-oeste desse território. Lançando mão de prédicas acerca da devoção e dos perigos da soberba, que ecoaram posteriormente por obras como a dos referidos Vicente Ferrer e Francisc Eiximenis, esse eclesiástico castelhano foi um dos primeiros a instruir os confessores hispânicos a ensinar os penitentes como confessar seus pecados. Nessa missão de revigoramento do sacramento da Penitência na Coroa de Castela, Pérez orienta os curas de almas para interrogar o penitente da seguinte forma:

da soberba demandarás, primeiro, se foi [o penitente] desobediente a Deus, pois o primeiro ramo da soberba é desobediência, por isso demande se passou

adaptação foi imprensa em Sevilha no ano de 1542 pelo impressor Juan de Villaquirán.

7 O livro foi dedicado a Sanxa Ximenes d’Arenós, condessa de Prades.

8 «No solament als religiosos és necessària la virtut de obediènce, hoc encara a tota gens del món. Car, con diu sent Ambròs, tots quans som, per força cové que siam obligats de obeir a tots los següens. Primeirament, a Déu totpoderós; e aquesta obediència és axf necessària que, segons que diu la santa Scriptura, sens ella no ns podem salvar» (Eiximenis 1981: 423). Versão em língua castelhana: Eiximenis siglo XV: f. 219v. Versão da obra Carro de las donas: Clausell Nácher 2007: 321.

9 Cf. Fernández Conde 2011: 402-403. 
os mandamentos de Deus. [...] [D]emanda se adorou a outra coisa senão a Deus, ou se amou a Deus mais que a todas as coisas, ou se amou alguma coisa do mundo mais que a Deus, e quanto tempo esteve em tal desobediência. ${ }^{10}$

O confessor devia ensinar ao fiel que a soberba representava um ato consciente de rebeldia contra as orientações divinas. ${ }^{11}$ Aos olhos de grandes autoridades, a soberba estava enraizada na vontade do fiel de seguir qualquer outro caminho que não fosse o da prática das virtudes e o da aceitação da Trindade (Casagrande e Vecchio 2003: 19-21).

Ao evidenciar esse tipo de ensinamento, Martín Pérez foi um dos primeiros a divulgar um conjunto de vocábulos em língua vernácula que nomeavam, entre outras matérias, o tipo de fiel decidido a romper com os mandamentos de Deus; vocábulos como «rebelde» (rebelde), «desobediente» (desobediente) e "soberbo» (sobervio). Um conjunto de palavras ganhavam luz para adjetivar a pessoa que não era humilde e preferia, por vontade própria, não confessar os pecados, não respeitar as solenidades religiosas, denegrir a imagem do prelado e causar tumultos. Dito de outro modo, Pérez foi importante para fixar um vocabulário específico do campo espiritual e ajudar confessores de diferentes partes a reconhecer o perfil de pecador com o qual deviam lidar cotidianamente no âmbito de suas paróquias. Vocabulário ese que foi se naturalizando, em solo castelhano-leonês, por meio da elaboração de volumosos tratados, de constituições de concílios e sínodos, bem como de reportationes ${ }^{12}$ de sermões como os de Vicente Ferrer.

Martín Pérez escreveu a obra Libro de las confesiones num período em que os reinos peninsulares estavam se adaptando às exigências do IV Concílio de Latrão de 1215, que obrigou os fiéis, por meio do estatuto Omnis utriusque sexus, a confessar anualmente os pecados mortais. Essa determinação foi exposta, de maneira mais ostensiva e clara, aos clérigos de Castela e outros reinos ibéricos durante o Concílio de Valladolid de 1322, em que o cardeal francês Guillaume Pierre Godin (Cf. Rucquoi 1990) apregoou:

Ninguém deve desprezar o sacramento da Penitência, que é necessária a todo fiel para se salvar, depois de haver chegado aos anos da discrição. Para tanto, mandamos com inteireza a todos os reitores de igrejas, sob pena de excomunhão, que em todos os domingos - desde a septuagésima ao menos até a Páscoa - se publique nas igrejas e em outros lugares onde se parece conveniente, a constituição do concílio geral que começa Omnis Utriusque Sexus, e, em especial, o relativo às penas dos que não confessam ou não comungam, que consistem em não lhes permitir em

10 «De la sobervia demandaras, primero, si fue desobediente a Dios, ca el primero ramo de la sobervia es desobediençia, por ende demanda si paso los mandamientos de Dios. Del primero demanda se adoro a otra cosa sinon a Dios, o si amo a Dios mas que a todas las cosas, o si amo alguna cosa del mundo mas que a Dios, e quanto tienpo estudo en tal desobediençia» (Pérez 2002: 154).

11 Acerca dos desdobramentos da prática da confissão, especialmente no que diz respeito aos seus usos como disciplina, ver: Reinhard 1994; Schiling 1994; Brambilla 2006: 21-22; Prodi 2005: 272-273.

12 Refere-se às cópias dos sermões realizadas por ouvintes. Uma discussão sobre esse assunto foi promovida por Pedro Cátedra (1984). No que diz respeito às características das reportationes, consultar Bataillon 1993. vida a entrada em igreja, e em morte privá-los de sepultura eclesiástica. ${ }^{13}$

Esse trecho, retirado de um dos principais concílios reformadores que ocorreu em solo ibérico no século XIV, reitera a necessidade de todos os vigários de paróquia precisarem não apenas instituir a confissão penitencial, mas também punir aqueles fiéis que se recusassem a se confessar. Nesse contexto de reordenamento pastoral da Igreja hispânica, a promoção do sacramento da Penitência fez com que o clero fosse imbuído da tarefa de divulgar as penas impostas a todos os homens e mulheres julgados não obedientes, tais como a expulsão das igrejas e a perda do direito de serem enterrados nos cemitérios sagrados. Essas penas funcionavam como meio para separar da comunidade os devotos e tementes daqueles menos comprometidos com seus deveres religiosos. Além disso, essas formas de punição também serviam para o fiel excomungado tomar consciência de seus atos e se sentir constrangido pela ofensa cometida.

Na primeira metade do século XIV, os clérigos da Coroa de Castela passaram a adotar uma política mais ordenada e sistemática de iniciação dos fiéis na prática dos sacramentos, como a Penitência e a Comunhão, ${ }^{14}$ bem como de constrangimento dos menos instruídos e dos rebeldes, para que não menosprezassem os mandamentos nem recusassem se confessar e comungar. Ganhando força em terras castelhanas, essa determinação do Concílio de Valladolid de 1322 ecoou por várias constituições sinodais dos séculos XIV e XV, como aquelas proferidas pelo bispo de Cartagena, Alfonso Fernández de Vargas, em um sínodo datado de 1352. Em certa altura do discurso, com o objetivo de efetivar as diretrizes promovidas pelo cardeal Guillaume Pierre Godin, o prelado asseverou que alguns cristãos não recebiam o sacramento da Eucaristia. Em razão desse problema, ele reproduziu em castelhano este trecho das regras de tal autoridade francesa: ${ }^{15}$ "mandamos a todos os prelados da santa Igreja, sob pena de excomunhão, que façam publicar a constituição do concílio geral, que diz Omnis utriusque sexus, em todos os domingos da Quinquagésima até a Páscoa em suas igrejas». Na sequência, o prelado diocesano afirmou que o fiel, ao evitar a confissão e comunhão, estaria vedado de entrar na igreja e ser enterrado em sepultura eclesiástica. ${ }^{16}$ Como se vê, o bispo Alfonso Fernández

13 «Nadie debe despreciar el sacramento de la penitencia, que es necessario a todo fiel para salvarse, despues de haber llegado a los años de la discrecion. Por lo tanto mandamos con entereza a todos los rectores de iglesias bajo pena de escomunion, que en todos los domingos desde seputagésima al menos hasta Páscua se publique en las iglesias, y en otros patrages en donde parecière conveniente, la constitucion del concilio general que empieza Omuns Utriusque Sexus, e en especial o relativo a las penas de los que no confesiesan o no comulgan, que consisten en no permitirles en vida la entrada en la iglesia, y en muerte privarles de sepultura eclesiástica» (Tejada y Ramiro 1851: 504).

14 Acerca da incursão da Igreja de Castela para corrigir os fiéis menos instruídos, ver Soto Rábanos 1995.

15 Quanto ao papel desse cardeal na Coroa de Castela, conferir Martin e Linage Conde 1987: 38-40.

16 «mandamos a todos los perlados de santa Yglesia, so pena de descomunion, que fagan publicar la costituçion del conçilio general, que dize Omnis utriusque sexus em todos los domingos de la Çinquajesima hasta Pascua em sus yglesias.' La qual costituçion dize 'que todo christiano que sea de edat confiese todos sus pecados fielmente a su proprio saçerdote al menos uma vegada en el año, e cunpla la penitençia que el dicho su confessor le diere, e resçiba com reverençia el Cuerpo de Jesuschristo 
de Vargas realizou uma tradução quase literal do trecho da constituição de Guillaume Pierre Godin citada acima, com o objetivo de obrigar todos os fiéis a confessarem seus pecados e se alinharem pelas diretrizes moralizantes que tinham de pautar toda a cristandade.

A constituição Omnis utriusque sexus do IV Concílio de Latrão começou, portanto, a ser atendida, nos bispados hispânicos, por meio dos desdobramentos do Concílio de Valladolid de 1322. A partir dessa data, os reinos da Península Ibérica - como o de Castela e Leão- procuraram convencer fiéis de diferentes lugares a professar os mesmos rudimentos. O combate à falta de obediência não apenas de clérigos ou religiosos, mas de mulheres e homens leigos tornou-se o desafio dessas autoridades para efetivar esses planos e fazer das dioceses hispânicas polos de formação de fiéis considerados exemplos de devoção. Partindo da correção de casos particulares, como as dificuldades que tinham leigos e clérigos de suas prelazias para cumprir os mandamentos da lei de Deus, os bispos deveriam mirar um alvo ainda mais difícil de atingir: persuadir os rebeldes e menos instruídos a seguirem os mesmos preceitos concernentes aos sacramentos e aos dogmas defendidos em qualquer outro canto da cristandade.

Pouco tempo depois do referido sínodo de Alfonso Fernández de Vargas, o bispo de Oviedo, Gutierre Gómez de Toledo denuncia - no sínodo de Oviedo do ano de 1379- que muitos fiéis, maliciosamente ou ignorância, não batizavam seus filhos. ${ }^{17}$ Com a finalidade de regulamentar a celebração do sacramento do Batismo, o bispo Gutierre Gómez de Toledo recomenda aos reitores e capelães que admoestassem os pais para levar os filhos às igrejas até seis dias depois do nascimento. Caso não atendessem a essa determinação e se comportassem como rebeldes, o correto era excomungá-los. ${ }^{18}$ Diretrizes como essa pululavam em Castela e ajudavam a direcionar a educação destinada aos homens leigos, punindo-os com duras penas e emendandoos com conselhos cada vez mais recheados de exemplos de comportamento e doutrinas cristãs.

Tais diretrizes de prelados diocesanos, confessores e pregadores mendicantes, mesclaram um discurso terno e brando - de descrição, por exemplo, da Paixão de Cristo ou do amor de Deu-com sermões carregados de um ar denso e punitivo. O clero falava da redenção e da esperança de um final melhor, porém focava especialmente a atenção no caminho duro que levava a essa conquista espiritual. Nesse momento de afirmação da prática dos sacramentos - especialmente o da confissão penitencial- e de contenção dos rebeldes, a pastoral cristã inovava ao fazer com que o confessor se aproximasse do fiel pecador para constrangê-lo e torná-lo responsável pelas consequências de suas ações. As

a los menos el dia de Pascua mayor, si no gelo vedase su confesor por alguna razon derecha; em otra manera, el que esto non fizere, em su vida seale defendida la entrada de santa yglesia, e em la muerte non aya eclesiastica sepultura» (Synodicon Hispanum 2013: 140).

17 «Et porque acaesçe a las vegadas que algunos, maliçiosamientre o por ynnorança, tiene las criaturas quando nasçen por baurizar por muchos dias, commo non deven» (Synodicon Hispanum 1984: 414-415).

18 «Et si algunos de los dichos feligreses et parrochanos, despues que fueren asi amonestados por sus rectores et capellanes, et fueren rebelles en lo asi non fazer et conplir, nos por esta carta de constituçion ponemos en ellos sentençia descomunion» (Synodicon Hispanum 1984 415). prédicas sinodais do universo hispânico dos séculos XIV e XV, embora continuassem a dar destaque aos desvios de clérigos e religiosos, criticando-os pelo concubinato e outros tipos de pecados relacionados ao relaxamento de seus deveres, conseguiram ampliar o seu escopo ao também produzir, em língua vernácula, um regimento para ordenar especificamente os deveres espirituais de homens e mulheres leigos. ${ }^{19}$

Uma das novidades desses tempos quanto à política pastoral era a relação de intimidade que deveria existir entre o fiel e seu confessor. Visando solidificar esse laço, Martín Pérez orientou o confessor, no Libro de las confesiones, a fazer a seguinte questão ao penitente: «foi desobediente aos seus pais espirituais, que são o bispo, o confessor e os padrinhos [...]?».. ${ }^{20}$ Esse jogo de obediência e aprendizagem, em que o cristão se colocava sempre como criatura imperfeita e carente de doutrina, era fundamentado por normas e conselhos elaborados por Martín Pérez e outros célebres autores eclesiásticos de Castela e outras plagas da cristandade. Visando firmar a mesma relação de obediência, o bispo de Ávila, Diogo de los Roeles - no dia 4 de julho de 1384, menos de setenta anos depois da elaboração do Libro de las confesiones-, afirma em suas constituições sinodais que o quarto mandamento da lei de Deus ensina a honrar, além dos pais, mães e padrinhos, aqueles que possuem a cura das almas, a saber, os pais espirituais. ${ }^{21}$ Atualizando uma tópica corrente da época, autores como Martín Pérez e Diogo de los Roeles inseriram a discussão acerca do elo entre o fiel e o confessor nos comentários concernentes ao quarto mandamento, justificando que os diretores de consciência eram os pais espirituais de qualquer cristão.

Essas prédicas tiveram vida longa e ecoaram por outros tratados e constituições sinodais do século XV. Um dos primeiros tratados castelhano-leoneses desse período a figurar na lista de referência dos confessores foi o Sacramental de Clemente Sánchez de Vercial, que se tornou um dos livros de maior circulação e vendagem no universo dos impressos ibéricos - não apenas em Castela, mas também em Portugal, onde obteve quatro impressões diferentes entre o final do século XV e início do XVI. Escrita entre 1420 e 1423 , essa obra assevera, no capítulo reservado ao quarto mandamento (Honrar pai e mãe), que dois dos vocábulos utilizados para dar nome a essa lei de Deus, "pai» e "honrar», tinham mais de um significado e, por isso, ganharam usos distintos no cotidiano das pessoas. A palavra «pai», no contexto da obra, possuía quatro usos diferentes, podendo significar "Deus», o "pai carnal», o "pai espiritual» (confessor e bispo) e o «rei»; já o verbo «honrar» era carregado de dois empregos bastante precisos. Explica o arcediago de Valderas que se podia honrar, tanto obras corporais, cuidando da vida deste mundo - exemplo possível seria a manutenção de sua casa e das suas terras-, quanto obras

19 Um dos estudos inspiradores para esta conclusão foi Soto Rábanos 1994. Ver também Sánchez Herrero 1995; Fernández Conde 1982; Rucquoi 1996; Ruiz-Gálvez Priego 2014.

20 «[...] demandaras se fue desobediente a los sus padres espirituales, que son el obispo e el su confesor e los padrinhos» (Pérez 2002: 176).

21 «El quarto mandamento es que devemos honrar a nuestros padres et a nuestras madres carnales et a nuestros padres et a nuestras madres spirituales, asi commo a nuestros padrinos e et a nuestras madrinas et aquellos que han cura de las nuestras animas, que son nuestros padres spirituales» (Synodicon Hispanum 1993: 17). 
espirituais, entendidas como a prática da «reverência e [da] obediência». Em relação ao ato de honrar as obras espirituais, Sánchez faz uma ressalva: «esta obediência deve ser diversa como os pais são diversos, pois ao prelado que é pai espiritual devemos obedecer nas coisas espirituais", e aos reis, nas coisas temporais; aos pais carnais, em tudo aquilo que recomenda o quarto mandamento. ${ }^{22}$ Mesmo que o fiel fosse súdito dos reis de Castela e Leão e deles obtivesse proteção, os padrinhos espirituais eram os únicos que deviam estar ao seu lado por toda a vida, aconselhando-o pessoaImente. Afinal, dos três "pais» - o carnal, o espiritual e o rei-, eram esses líderes religiosos que o absolveria dos pecados mortais e cuidaria da saúde de seu espírito.

FIGURA 1

\section{Sacramental}

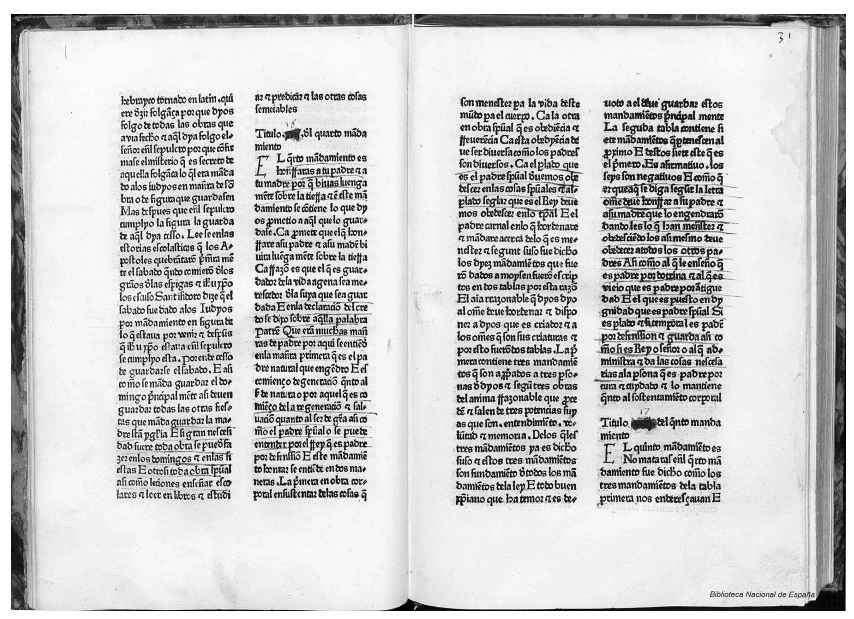

Fuente: Sánchez [1475-1476?]: f. 30v-31

O rompimento do laço de obediência com os pais espirituais foi condenado por muitos tratados de confissão, como o Breve forma de confisón do bispo de Ávila, Alonso de Madrigal, que obteve ao menos cinco impressões no final do século XV e limiar do XVI. Visando estabelecer limites para as ações dos penitentes, declara essa obra que a desobediência era praticada, entre outras circunstâncias, a partir do momento em que o fiel não respeitasse os bispos, vicários ou outras figuras eclesiásticas. ${ }^{23}$ Nesse período em que aumentava o número de livros destinados ao fomento do sacramento da Penitência, o fiel considerado desobediente e o religioso que não seguia as orientações de seu abade eram taxados com o mesmo adjetivo: o de soberbos. Aliás, a relação penitente/confessor estava alicerçada num jogo de obediência semelhante ao que pautava o vínculo entre o abade e o monge, pois - guardadas as diferenças concernentes ao modo de vida cada um deles- em ambos os casos havia uma figura que assumia o papel de guia espiritual da outra. Entre a promulgação das constituições do cardeal francês Guillaume Pierre Godin e a impressão de tratados

22 «Ca esta obedyẽcia deue ser diuersa como los padres son diversos. Ca el plado que es el padre spũal ouemos obedescer em las cosas spũales» (Sánchez [1475-1476?]: f. 31).

23 «Esso mesmo la desobediencia es cerca de los perlados assi como si alguno non obedesca el mandamiento de los perlados spirituales assim como de los obispos, o vicarios o semejantes» (Madrigal 1996: f.8r). como o Breve forma de confisón e o Vergel de Consolaçión del alma que será citado abaixo, Castela assistia ao fortalecimento, portanto, de um regimento voltado à emenda e ao constrangimento dos fiéis leigos, o qual fora inspirado na própria disciplina religiosa, como convém agora analisar.

\section{HUMILDADE VERSUS HIPOCRISIA E REBELDIA}

Impresso na cidade de Sevilha no ano de 1497, o Vergel de Consolaçión del alma atribuído a Jacobo de Benavente ajudou leigos e membros do clero a aprender um conjunto de virtudes tidas como fundamentais para a vida cotidiana. Ao estimular a prática da virtude da obediência, esse guia espiritual afirma: «foi o primeiro homem expulso do Paraíso por desobediência, porque não quis obedecer aos mandamentos de Deus. E, por isso, se nós queremos subir ao lugar de onde ele foi expulso, sejamos obedientes». ${ }^{24}$ Utilizando as palavras de S. Jerônimo, um dos padres do cristianismo, a obra Vergel de Consolaçión visava convencer o fiel cristão de que a obediência a Deus e ao seu superior eram as únicas maneiras de se evitar a prática dos pecados e a perda do Paraíso ou da graça divina. Era um consenso entre teólogos e canonistas que o fiel não conseguiria ser mestre de si sem ajuda de um confessor ou do bispo, isto é, de um diretor de sua consciência, a fim de fazê-lo superar cada adversidade e se redimir pelos pecados cometidos (Cf. Gilson 2006: 288).

Seguindo os passos de outros autores de guias moralizantes da época, o Vergel de Consolaçión del alma considera que a virtude contrária à soberba de homens que se recusavam a obedecer aos seus superiores era a "humildade». Assevera esse livro: "Cristo ama a humildade dos confessantes e não o contradizer dos soberbos, que inclinam seu coração em palavras de malícia como desculpa e defesa de seus pecados». Logo na sequência, adita tal florilégio que o «justo começa, primeiramente, a ser acusador de si mesmo", sabendo como ser humilde para reconhecer o erro e corrigir sua consciência. ${ }^{25}$ Essas passagens do Vergel de Consolaçión formam um grande receituário, recheado de conselhos e admoestações, em que o leitor encontraria amparo espiritual para a prática correta de sua devoção - uma devoção que não poderia ser contemplada, desse modo, sem a humildade e a realização do sacrifício de si por meio da confissão e da penitência. (Cf. Casagrande e Vecchio 2003: 36).

Os manuais de confessores e outros tipos de obras pastorais, como o Vergel de Consolaçion del alma, atualizaram um jogo de palavras que definiam valores, como a humildade, cujo uso as remetia ao universo monástico, especialmente às Regras religiosas. Penetrando no terreno da construção de admoestações e conselhos para os penitentes, esse conjunto de livros foi fundamental para que se criasse um corpus de diretrizes para combater os pecados mortais, inspirado na rigidez da vida cenobítica e na

24 «Dize jeronimus: por desobediencia fue el primero hombre sacado del parayso, por que non quiso obedescer los mandamientos de dios. E por ende si nos queremos subir donde el fue sacado seamos obedientes» (Benavente 1497: f.23v).

25 «xps ama la humildad de los confessantes e no el contradizer de los sobervios que inclinan su coraçon en palabras de malicia por escusaciones e defensiones a sus pecados. El justo primeiramente comiença de ser acusador de si mismo» (Benavente 1497: f.20v). 
obediência esperada do monge em relação ao seu superior. Acerca do papel da disciplina religiosa no sentido de fomentar regras para os leigos, o tratado La summa de confession llamada defecerunt - do arcebispo de Florença, frei D. Antonino, cujo sucesso em língua vernácula em Castela o fez ser editado várias vezes na passagem do século XV ao XVI- traz um catálogo dos doze degraus de humildade. Repercutindo as bases da Regra de S. Bento, esse catálogo procura motivar o fiel a evitar a curiosidade (primeiro grau); falas excessivas e voz descontrolada (segundo degrau); alegria vã (terceiro grau); "alabança» (quarto grau); ${ }^{26}$ parecer mais santo do que é (quinto grau); ${ }^{27}$ arrogância (sexto grau); presunção (sétimo grau); defesa de seus pecados (oitavo grau); falta de paciência (nono grau); rebeldia (décimo grau); o deleite sem limite (décimo primeiro); e desprezo de Deus (décimo segundo) (Antonino Florencia 1505:f.31r, 31v). Em linhas gerais, essa lista deveria ser utilizada pelo confessor durante a confissão para abrandar os fiéis não devotos e que não desejavam obedecer às égides dos mandamentos, proporcionando aos leigos, nobres e pessoas comuns, recomendações que durante muito tempo eram reservadas apenas aos monges e outros tipos de religiosos.

FIGURA 2

La summa de confession Ilamada defecerunt

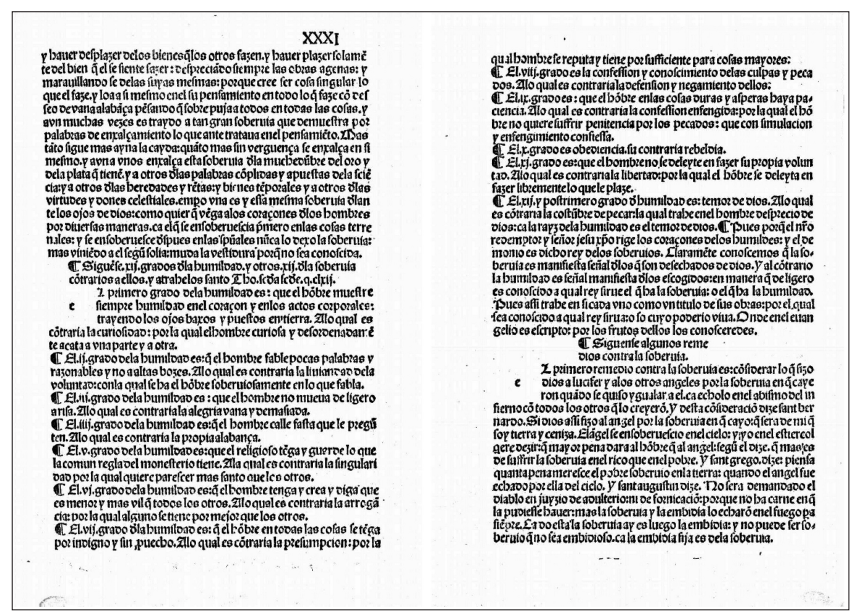

Fuente: Antonino Florencia 1505:f 31r, 31v.

O tema da humildade ou o dos riscos da soberba eram recorrentes na produção edificante da Igreja hispânica. Visando punir os desobedientes, o religioso Francisc Eiximenis, na citada obra Llibre de les Dones, é categórico ao afirmar: «Dizia o santo abade Moisés que os homens desobedientes e afastados do mundo de Deus eram naturalmente rústicos ${ }^{28}$ vilões, porque não sabem dar a Deus honra, nem reverência». ${ }^{29}$ Aos olhos de Eixemenis, os fiéis não obedien-

26 «Alabancia: Alabanza, jactancia» (Real Academia Española 2001: 83).

27 É o único destinado especificamente aos religiosos.

28 «Rústico» era um adjetivo que caracterizava ora uma pessoa do campo, ora uma pessoa «tosca». Cf. (Martín 1986: 1563).

29 «Deya lo sant abat Moysès que gran disposición ha a inobediència l'om qui és naturalment rústech e pagès que a res no sap dar honor ne reverència. Aquests appellava Sèneca, en una sua epístola, àsens e fills d'àsens» (Eiximenis 1981: 421). Versão em língua castelhana: Eiximenis, [séc. XV] f. 220v. Versão do Carro de las donas: Clausell Nácher 2007: 320. tes e avessos à prática da humildade acreditavam que eles mesmos se bastavam, na medida em que não necessitavam obedecer a outra pessoa para terem seus pecados corrigidos. Essa conduta resulta - segundo outros pensadores, tais como Guillaume Peyraut, teólogo dominicano do século XIII- de um "orgulho intelectual», ou seja, de uma atitude de enaltecimento de si e de não reconhecimento dos bens ofertados por Deus (Casagrande e Vecchio 2003: 48).

Esse tipo de conselho, sobre a maneira de corrigir o «orgulho intelectual» e outras formas de soberba, era prescrito não apenas por volumosos tratados como o Llibre de les Dones de Francisc Eiximenis, mas também por escritos destinados a ajudar pregadores a elaborar seus sermões. É o caso da obra Evangelios Moralisadores, do religioso dominicano Juan López de Salamanca, escrita provavelmente por volta do início da segunda metade do século $\mathrm{XV}$, em que ele destaca uma paráfrase de três textos bíblicos, de Mateus (Mt. 21: 4,5), Judite (Jt. 9: 16) e o Cântico dos Cânticos, ${ }^{30}$ a fim de abordar a humildade. Explica esse religioso que Cristo quis ser manso e, por isso, mostrou humildade de três maneiras diferentes: ao perdoar os pecados, ao fazer o bem, e ao padecer pelos cristãos. Evidenciando momentos inspiradores da vida de Cristo para estimular a humildade e combater a soberba, esse letrado procurou convencer o fiel a se alinhar à mensagem desses textos bíblicos, que propõem a mansidão como caminho para o abrandamento do corpo e a conquista do Paraíso (López de Salamanca 2004: 92).

Juan López de Salamanca utiliza um trecho do Evangelho de Mateus como síntese dessa lição, a saber: "aprendei de Mim, que sou manso e humilde de coração». (Mt. 11, 29)..11 Nessa citação, as próprias palavras de Cristo foram mencionadas para estimular o ouvinte da prédica a refletir sobre suas ações passadas, com o objetivo de evitar que a soberba prevalecesse em detrimento da mansidão. Cruzando textos bíblicos como o de Mateus e Judite, a Escritura fornece ao dominicano não apenas um repertório temático, mas também instrumentos retóricos; melhor dizendo, as referidas passagens bíblicas proporcionam um conjunto de recursos que ajudariam o público alvo dos sermões (Casagrande 2014: 229-230). A leitura de textos sobre a vida e as virtudes de Cristo servia para sensibilizar os ouvintes da prédica e lhes despertar a vontade de naturalizar a mansidão. Mais precisamente, por meio do sermão a respeito da humildade, esperava-se retirar lágrimas dos ouvintes, cativando-os com as virtudes vivenciadas por Cristo.

Todavia, para aprenderem a ser humildes e seguir os passos de Cristo, os fiéis precisavam evitar outro pecado: a hipocrisia. Martín Pérez ensina ao confessor que certos fiéis pecadores praticavam ações devotas apenas para se vangloriar delas e obter reconhecimento de seu grupo. Diz esse eclesiástico, no Libro de las confesiones, que o cura de almas deveria restringir a sua arguição a questões pontuais sobre as motivações do pecador que quer se passar por devoto e realizar «coisas de bondade e de santidade». ${ }^{32}$

30 O editor do documento, Artur Jiménez Moreno, diz não haver um correspondente exato do trecho na Bíblia atual (López de Salamanca 2004: 92).

31 «deprended de mí, que manso soy e humilde de coraçón» (López de Salamanca 2004: 92).

32 «De la ypocresia, que es otrosi ramo de sobervia. demandaras. Ypocresia es dezir o fazer cosas de bondat e de santidat por que tengan 
Uma das consequências da adoção de diretrizes como essa de Martín Pérez foi o aumento do número de críticas aos atos pecaminosos praticados não apenas aos domingos, mas também durante procissões, atos fúnebres, casamentos e outras celebrações em que se exigia do fiel concentração, devoção e respeito.

Os próprios bispos relatavam casos em que fiéis excomungados fingiam não ser condenados e frequentavam missas e outras cerimónias. Um desses prelados diocesanos foi o bispo de Cuenca, Diego de Anaya y Maldonado. Em 1413, essa autoridade eclesiástica abre espaço em um sínodo para coibir a ação de fiéis excomungados, tidos como os mais desobedientes da diocese, ao apregoar que havia muitos deles nas cidades, vilas e outros lugares que perseveravam "em sua rebeldia» e permaneciam com "seus corações endurecidos». Para piorar o quadro, o prelado ainda reporta que esses homens frequentavam igrejas, viviam sem sentir medo de estarem nessa condição e se tornavam maus exemplos para outras pessoas (Synodicon Hispanum 2011: 175-176). Visando refrear a atuação dos rebeldes e excomungados, o referido bispo propôs no sínodo que todos os párocos confeccionassem cédulas com o nome de cada um deles e as enviassem para as paróquias vizinhas e mosteiros, a fim de que todos pudessem conhecer essa gente. ${ }^{33}$

Além de problemas enfrentados com os excomungados, Diego de Anaya y Maldonado, no mesmo sínodo de Cuenca de 1413 , também relatou casos de fiéis que dançavam e cantavam durante as vigílias. Assim como outros prelados diocesanos de Castela, esse bispo de Cuenca afirmou que transgressores, sentenciados à excomunhão, promoviam danças dissolutas e jogos em lugares em que deveriam apenas orar e manifestar a sua fé. ${ }^{34} \mathrm{Em}$ outra diocese da Coroa de Castela — no ano de 1497, oitenta e quatro anos

los omes buena opinion del e que lo tengan por bueno, e el mismo se cuyda que es bueno e por tal se entiende, e esta buena opinion non la quiere el sinon para gloriarse en ella. Aqui se podrian demandar muchas cosas, mas es peligro, e non demandes sinon se diz o dixo por que le toviesen por bueno, ayunos, lagrimas e oraçiones e vigilias, predicaçiones e limosnas; e quequier que sea que fizo o dixo por aver opinion e fama de santiat, todo lo confiese» (Pérez 2002: 178).

33 «Otrossi, fuenos pedido por merçed que a la nuestra señoria plega que por quanto ay munchos descomulgados em la çibdad e villas e lugares del nuestro obispado fasta de anathema, los quales perseveran en su rebeldia e non quieren salir de las dichas sentençias en que anssi estan ligados con coraçones enduresçidos, e andan publicamente e partiçipan com los fieles christianos, commo si non estudiessen descomulgados. E que esto nasçe porque son denuçiados por excomulgados em la dicha çibdad e villas en una yglesia e non lo fazen saber a los clerigos de las otras yglesias, e con poco temor de Dios e con menospreçio de las sentençias de la sancta madre Yglesia e em grand peligro de sus animas oyen missas em las yglesias e monesterios <en> que non son denunçiados, lo qual es escandalo de los pueblos. Sobre lo qual nos fue pedido que lo proveyesemos segund que cunple a la salud de las animas de los nuestros subditos, mandando que quandoquier que alguno fuere descomulgado en una yglesia, que los clerigos della enbien çedulas a todas las otras yglesias e monesterios de la villa doquier que acaesçiere, para que denunçien al tal por excomulgado» (Synodicon Hispanum 2011: 175-176).

34 «Otrossi, por quanto nos oviemos ordenado en la sancta sinodo que çelebramos en la nuestra villa de Pareja que todas las perssonas que oviessen devoçion de yr velar a algunas yglesias del dicho nuestro obispado que fuessen a las dichas yglesias honestamente e llevassen çera e azeyte para conplir sus votos, e non cantassen nin fiziessen otras danças disolutas en las dichas yglesias, por quanto, so espeçie de devoçion se fazian munchas burlas» (Synodicon Hispanum 2011: 178-179). depois da realização desse sínodo em Cuenca- o bispo de Salamanca, Diego de Deza, condenou fiéis rebeldes que não respeitavam a solenidade dos casamentos. Segundo o prelado, eles celebravam os casamentos com risos e jogos, de modo que não mostravam a honra e reverência esperada nesse tipo de ocasião. ${ }^{35}$ Prédicas como essas de Diogo de Deza, Diego de Anaya y Maldonado, Martín Pérez e de Juan López de Salamanca foram fundamentais, portanto, para a promoção, em solo castelhano, de uma disciplina a ser vivenciada por homens leigos de diferentes origens e condições sociais.

\section{VIGÍLIA E ABSTINÊNCIA}

Para encerrar este estudo da proposta moralizante da Igreja de corrigir os fiéis não obedientes, falta explorar outro eixo da produção eclesiástica: o agenciamento de um ritmo de vida hebdomadário. Uma das principais missões que a Igreja assumiu ao disciplinar os fiéis - especialmente os rústicos, isto é, aqueles dos campos e vilarejos - era ensiná-los a pautar o tempo e as atividades manuais e litúrgicas pelos dias da semana, respeitando os domingos como momentos sagrados. Quanto à regulação do domingo, a obra Los Diez mandamientos con su glosa -escrita provavelmente no final do século XIII e traduzida para o português no limiar do século XV pelo mosteiro de Alcobaça-, assevera que o fiel precisava praticar a abstinência e reverência para se guardar de todo lavor temporal no domingo e dias festivos. ${ }^{36}$ Logo no início da glosa do terceiro mandamento, esse opúsculo enfatiza que era necessário haver abstinência em toda a pessoa, «nos olhos, orelhas, boca, língua, garganta, mãos, coração", de modo que o corpo estivesse em repouso e a cabeça concentrada apenas em atividades litúrgicas ou de devoção.

No século XIV, poucos escritos e concílios realizados em solo hispânico nesse período foram tão explícitos quanto à obrigação de poupar o corpo aos domingos como esse opúsculo sobre os mandamentos ou o já mencionado Concílio de Valladolid de 1322. Nessa ocasião, o cardeal francês Guillaume Pierre Godin apregoou:

Ainda que por preceito da lei divina está mandado que nos domingos e dias festivos não se trabalhe em obras servis, no entanto, alguns em transgressão a este mandado se exercitam em tais dias em trabalhos rústicos e em artifícios. E para que por este pecado o povo fiel não incorra na indignação de Deus Onipotente, estabelecemos que nos domingos e dias festivos ninguém se atreva a cultivar campos, nem a dedicar-se a

35 «Mandamos, por que los dichos inpedimientos e los otros peligros que pueden aconteçer çera de los matrimônios se puedan conosçer e saber, e, sabidos, se puedan escusar, que se çelebren com onra e reverençia em los casos por el derecho otorgados, e non com rysa nun de juego, nun de noche nin ascondidamente, mas de dia e publicamente em la faz de la Eglesia» (Synodicon Hispanum 1987: 283).

36 «Dos cosas faze menester a cada uno que bien quiera guardar las fiestas: abstinençia e rereverençia en muchos conciene de todo en todo; luego guarse deve de todo labor temporal, que non la labre en el domingo, nijn en los dias santos» (Pascual 1907: 7). Há uma recente edição em francês, com estudo introdutório, da versão em português dessa obra: (Teodoro 2017). O mesmo autor da tradução para o francês elaborou uma antología, intitulada Guias dos costumes cristãos, em que editou ese opúsculo em português (Teodoro 2019). 
obras manuais sem urgente necessidade ou evidente causa de piedade [...]. Os ordinários excomungam os transgressores desta constituição. ${ }^{37}$

Essa constituição foi outra determinação de Guillaume Pierre Godin que ajudou os bispos hispânicos a saberem como cuidar das almas dos fiéis, ensinando-os a proibir qualquer tipo de serviço braçal nos dias de solenidades da Igreja. Além disso, esse tipo de orientação foi importante para os cristãos da Coroa de Castela e outras partes da Península Ibérica começarem a familiarizar-se, de maneira mais regular e sistemática, com o calendário litúrgico.

Prédicas como essa ganharam terreno nos sínodos e foram reproduzidas por constituições sinodais como a elaborada pelo bispo de Ávila, Diego de los Roeles, no ano de 1384. Durante o sínodo, esse prelado apregoou que «o terceiro mandamento é que o homem guarde e honre as festas dos domingos e outras festas» estabelecidas pela Igreja. Segundo ele, as pessoas agiam contra esse mandamento por lavrarem e trabalharem na terra, ou fazerem comércio no dia de domingo. ${ }^{38}$ No que concerne à manutenção de uma rotina hebdomadária, se as Regras deviam instruir os monges em relação às suas atividades semanais, as constituições de sínodos e concílios foram imbuídas da obrigação de estender esse ritmo de vida aos clérigos seculares e leigos, ensinando-os a dividir o tempo em dias. Acerca desse mesmo preceito, o tratado La Summa de Confession Llamada Defecerunt - do arcebispo de Florença, frei D. Antonino-, assim como outras obras do mesmo gênero, visavam convencer fiéis a respeitar o domingo a partir de glosas do terceiro mandamento Florencia 1505: f.21r). Em outros tratados de grande circulação, como o Sacramental, de Clemente Sánchez de Vercial, também existem prédicas semelhantes a esta, de modo que não faltaram obras cujo propósito era ensinar aos confessores, entre outras lições, a necessidade de todo fiel respeitar os dias de domingo. ${ }^{39}$

Ainda no que trata da naturalização do terceiro mandamento em língua castelhana, o célebre arcebispo de Granada e confessor da rainha D. Isabel, o religioso jerônimo Hernando de Talavera, ${ }^{40}$ contribuiu para que os fiéis respeitassem o dia de domingo a partir de algumas de suas obras,

37 «Aunque por precepto de la ley divina está mandado que en domingos y dias festivos no se trabaje en obras serviles; sin embargo, algunos en contravencion a este mandato se ejercitan en tales dias en trabajos rústicos y en artificios. Y para que por este pecado el pueblo fiel no incurra en la indignacion del Dios Omnipotente, establecemos que en los domingos y dias festivos nadie se atreva a cultivar campos, ni a dedicarse a obras manuales sin urgente necessidad, o con evidente causa de piedad; y aun en estos casos lo harán con permiso especial del sacerdote. Los ordinarios escomulgarán a los transgresores de esta constituccion» (Tejada y Ramiro 1851: 481).

38 «El terçero mandamiento es que el ome guarde et honre las fiestas de los domingos et las otras fiestas que son establesçidas solepnemente por la Eglesia para que sean guardadas. Contra este fazen los que labran et trabajan en las fiestas en sus menesteres o en tierres o en possessiones o fazen mercado et los que non oyen missa, non aviendo escussaçion legitima, a lo menos el dia del domingo» (Synodicon Hispanum 1993: 17).

39 No que tange à regulação do domingo na Espanha medieval, conferir Fernández Conde 1982: 294.

40 Acerca do papel social e política de Hernando de Talavera, ver: Isabella lannuzzi, El poder de la palabra en el siglo XV: Fray Hernando de Talavera. como Católica Impugnación -escrita em $1481^{41}$ para combater os argumentos de um libelo judaizante que circulava pelas ruas de Sevilha da época. Em certa altura, ao justificar que Cristo havia conferido às leis mosaicas um novo uso e atualizado as suas bases, afirma o papel Dele para a inovação da leitura cristã do terceiro mandamento. Combatendo os alicerces das regras dos judeus de seu tempo, Talavera defende que foi o Filho de Deus o responsável por tornar o domingo o dia do repouso, e não o sábado como a tradição de Sua época determinava. Além disso, Cristo teria inovado ao ensinar os cristãos a também guardar os outros dias festivos. ${ }^{42}$ Dado o esforço de proteger os andaimes morais do terceiro mandamento, esse religioso foi outro prelado da Coroa de Castela a estimular os fiéis católicos a evitar o costume judaico e aceitar o dia de domingo como santo e, por isso, propício para as orações e outras práticas devocionais.

Na primeira metade do século XVI, parte das admoestações dos prelados quatrocentistas, como essa defesa do terceiro mandamento, continuaram a ser apregoadas em sínodos. Numa altura em que as constituições do Concílio de Valladolid de 1322 já haviam sido incorporadas às obras de muitos outros prelados, e na mesma esteira das autoridades diocesanas aqui citadas, o bispo de Cuenca, Diego Ramirez de Villaescusa, afirmou num sínodo de 1531 que as pessoas de povoados e campos praticavam grande corrupção por não respeitarem os dias festivos da Igreja. A solução por ele encontrada foi declarar que os homens desses lugares não poderiam mais levar bestas para as igrejas e frequentar tabernas ou comércios nos dias das celebrações litúrgicas. ${ }^{43}$ Para formar os fiéis nos ditames da Igreja, esse prelado inseriu lavradores e outras personagens campestres num ritmo de vida inteiramente cristão, fazendo-os respeitar as celebrações e ouvir atentamente a fala dos párocos.

As obras mencionadas neste trabalho, como os livros de Martín Pérez, Jacobo de Benavente, Francisc Eiximenis, Antonino de Florença e de outros letrados da Igreja, ajudaram os confessores da Coroa de Castela a preparar as suas prédicas e a saber como admoestar os fiéis para que naturalizassem virtudes como a obediência e a humildade. Entre diferentes tipos de prédicas, não faltavam admoestações e conselhos voltados especificamente para combater o pecado da soberba e ensinar os cristãos a evitar a rebeldia

41 A obra foi impressa no ano de 1487.

42 «Innovó el tercero mandamiento, que era guardar el día septeno, que vulgarmente es llamado sábado, mandando guardar, como adelante parcerá, el dia primero o el octavo, que es día llamado domingo, que quere decir, del Señor. Aun innovóle, enseñando en qué manera se ha de guardar este santo día y otra cualquier pascua o fiesta, que es, vacando a nuestro Señor a las obras de piedad y a las que para nuestra sustentación en tales días no se pueden buenamente escusar» (Talavera 2012: 32).

43 «Porque en la guarda de las fiestas hallamos que ay grande corrupcion y que ni en los poblados ni en los campos se guardan, y para reprimir la osadia de los que com poco temor de Dios las quebrantan, sancta synodo approbante, estatuymos e mandamos que ninguno, em poblado ni en el campo, haga obra servil quebrantando la fiesta, ni trayga bestias cargadas, y que, em tañiendo a la missa mayor, todos los que tienen tiendras de qualquier mercaderia las cierren, y qye los taberneros ni mesonemissa mayor de aquel lugar sea del todo acabada. Los que lo contrario hizieren trabajando em dias de fiestas o trayendo bestias cargadas o teniendo las tendas abiertas, por cada vez que lo hizieren caygan em pena de veynte maravedis, de los quales aya la mitad el alguazil que lo executare y la otra mitad la yglesia parrochial del lugar donde las fiestas fueren quebrantadas» (Synodicon Hispanum 1981: 419). 
e outros pecados decorrentes da falta de mansidão. Em outras palavras, havia uma preocupação por parte da Igreja da Coroa de Castela, partilhada por clérigos de outros lugares, de abrandar o coração de fiéis que se recusassem a obedecer ao confessor, bem como de aconselhar que se evitasse a companhia de homens e mulheres taxados de rebeldes.

O fiel iniciado nos dogmas da Igreja deveria aprender, portanto, a seguir um regime de doutrinas e não se rebelar contra as penas impostas pelos seus padrinhos espirituais, o bispo e o confessor. Em síntese, muitas recomendações de clérigos e religiosos da Castela dos séculos XIV e XV, ressoando determinações correntes em outras plagas cristãs, visavam convencer homens e mulheres de que a salvação dependia da obediência e da paciência. A partir dessas medidas, começou-se a ensinar aos leigos, de maneira mais constante nesse período, a importância de reconhecer o perdão como uma conquista meritória que exigia uma postura humilde para reconhecer as próprias limitações ao confessar suas faltas.

\section{BIBLIOGRAFIA}

Baloup, D. 2003. "L'enseignement et les pratiques du salut en Castille au XVe siècle». En D. Baloup, L'enseignement religieux dans Ia Couronne de Castille. Incidences spirituelles et sociales (XIIle-XVe siècle): 105-124. Madrid: Casa de Velázquez.

Bataillon, L.-J. 1993. "Sermons rédigés, sermons réportés (XIIIe siècle)». En L.-J. Bataillon, La prédication au XIIle siècle en France et Italie: Études et documents: 68-86. Variorum Collected Studies Series. Brookfield: Ashgate Publishing Company.

Benavente, J. de. 1497. Vergel de Consolación. Sevilla: Meinardo Ungut y Estanislao Polono.

Braeckmans, L. 1971. Confession et communion au Moyen Âge et au Concile de Trente. Gembloux, Belgique: J. Duculot.

Brambilla, E. 2006. La Giustizia Intolerante. Inquisizione e Tribunali Confessionali in Europa (secoli IV-XVIII). Roma: Carocci.

Casagrande, C. 2014. "Sermo Potens. Rhétorique, grâce et passions dans la prédication médiévale». En N. Bériou, J.-P. Boudet e I. Rosier-Catach, Le pouvoir des mots au Moyen Âge: 225-237. Turnhout, BE: Brepols.

Casagrande, C. e Vecchio, S. 2003. Histoire des péchés capitaux au Moyen Âge. Paris: Aubier.

Cátedra, P. M. 1984. "La predicación castellana de san Vicente Ferrer». Butlletí de la Reial Acadèmia de Bones Lietres de Barcelona 39: 235-309.

Cátedra, P. M. 1994. «Parte Primeira». En P. M. Cátedra, Sermón, sociedad y literatura en la Edad Media. San Vicente Ferrer em Castilla (1411-1412): estúdio bibliográfico, literario y edición de los textos inéditos: 11-99. Salamanca: Junta de Castilla y León; Consejería de Cultura y Turismo.

Eiximenis, F. 1981. Lo libre de les dones. Edición crítica a cargo de Frank Naccarato. Barcelona: Curial Edicions Catalanes.

Eiximenis, F. Libro llamado de las Donas. Manuscrito BH MSS 153 localizado na Biblioteca Histórica Marqués de Valdecilla da Universidad Complutense de Madrid s. I.: s. n., s. XV.

Fernández Conde, F. J. 1982. "Religiosidad popular y piedad culta». En R. García-Villoslada, Historia de la Iglesia en España. La Iglesia en la España de los siglos VIII-XIV: 289-357. Madrid: Biblioteca de Autores Cristianos.

Fernández Conde, F. J. 2011. La religiosidad medieval en España. Baja Edad Media (siglos XIV-XV). Asturias: Ediciones Trea.

Ferrer, V. 1994. "Sermón 3», en P. M. Cátedra, Sermón, sociedad y literatura en la Edad Media. San Vicente Ferrer en Castilla (14111412): estúdio bibliográfico, literario y edición de los textos inéditos: 285-297. Salamanca: Junta de Castilla y León, Consejería de Cultura y Turismo.
Florencia, A. d. 1505. La summa de confession llamada defecerunt de Fray Anthonino Arçobispo de Florencia del Orden de los Predicadores. Salamanca: Hans Gysser.

Gilson, É. 2006. O Espírito da Filosofia medieval. Trad. E. Brandão. São Paulo: Martins Fontes.

lannuzzi, I. 2009. El poder de la palabra en el siglo XV: Fray Hernando de Talavera. Salamanca: Junta de Castilla y León.

López de Salamanca, J. 2004. Evangelios moralizados. Ed. Arturo Jiménez Moreno. Salamanca: Ediciones Universidad de Salamanca.

Madrigal, A. d. 1996. Breve forma de confesión. Ed. F. D. Fernández. Santiago de Compostela: Xunta de Galicia.

Martín, A. 1986. Diccionario medieval español (Vol. Tomo II). Salamanca: Universidad Pontificia de Salamanca.

Martin, J. L. e Linage Conde, A. 1987. Religion y sociedad medieval. El catecismo de Pedro de Cuéllar (1325). Salamanca: Europa Artes Gráfica.

Nácher, C. 2007. Carro de las donas, Valladolid, 1542. Madrid; Salamanca: Fundación Universitaria Española; Universidad Pontificia de Salamanca.

Pascual, S. P. 1907. "Glosa de los Diez Mandamientos». En F. P. Valenzuela, Obras de Pedro Pascual Mártir (Vol. III). Roma: Imprenta Salustiana.

Pérez, M. 2002. Libro de las confesiones, Una radiografía de la sociedad medieval española, edición de Antonio García y García, Bernardo Alonso Rodríguez y Francisco Cantelar Rodríguez. Madrid: BAC.

Prodi, P. 2005. Uma história da justiça. São Paulo: Martins Fontes.

Real Academia Española. 2001. Diccionario de la lengua española (ed. 22, Vol. 1). Madrid: Espasa.

Reinhard, W. 1994. "Disciplinamento Sociale, Confessionalizzazione, Modernizzazione. Un Discurso Storiografico». En Paolo Prodi e Carla Penuti (coords.), Disciplina dell'Anina, disciplina del Corpo e Disciplina della Società tra Medioevo ad Età Moderna: 101-123. Bolonha: Società Editrice II Mulino.

Rucquoi, A. 1990. «El cardenal legado Guillaume Peyre de Godin». Revista Española de Derecho Canónico 47: 493-516.

Rucquoi, A. 1996. "Éducation et société dans la Péninsule ibérique médiévale». Histoire de l'éducation 69: 3-36. https://doi. org/10.3406/hedu.1996.2806

Ruiz-Gálvez Priego, E. 2014. «La fortaleza de la fe: en torno al principio de fe: en sus implicaciones sociales y devocionales (Castilla, siglos XIII-XV)». En I. B. PITA, Poder, piedad y devoción: Castilla y su entorno (siglos XII-XV): 261-318. Madrid: Sílex.

Sánchez, C. ([1475-1476?]). Sacramental. [Burgos?]: [Fadrique de Basilea?].

Sánchez Herrero, J. 1995. "Catequesis y predicación». En B. B. Martínez, Historia de la acción educadora de la iglesia en España, Vol. 1: 204-233. Madrid: Biblioteca de Autores Cristianos.

Schiling, Heinz. 1994. "Chiese Confessionali e Disciplinamento Sociale. Un Bilancio Provvisorio della Ricerca Storica». En Paolo Prodi e Carla Penuti (coords.), Disciplina dell'Anina, disciplina del Corpo e Disciplina della Società tra Medioevo ad Età Moderna: 125-160. Bolonha: Società Editrice II Mulino.

Soto Rábanos, J. M. 1994. «La ignorancia del Pueblo Cristiano llano, un obstáculo para el diálogo interrreligioso». En H. Santiago-Otero (éd.), Diálogo filosófico-religioso entre cristianismo, judaísmo e islamismo durante a Edad Media en la Península Ibérica. Actes du Colloque international de San Lorenzo de El Escorial, 23-26 juin 1991, organisé par la Société internationale. Turnhout: Brepols.

Soto Rábanos, J. M. 1995. "Pedagogía medieval Hispana: transmisión de saberes en el bajo clero». Revista Española de Filosofía Medieval 2: 43-58. https://doi.org/10.21071/refime.v2i.9742

Synodicon Hispanum III - Astorga, Leon y Ovidedo. 1984. Dirigido por García y García, A. Madrid: Biblioteca de Autores Cristianos.

Synodicon Hispanum. IV - Ciudad Rodrigo, Salamanca y Zamora. 1987. Dirigido por García y García, A. Madrid: Biblioteca de autores cristianos.

Synodicon Hispanum.VI - Ávila y Segovia. 1993. Dirigido por García y García, A. Madrid: Biblioteca de Autores Cristianos.

Synodicon Hispanum. X-Cuenca y Toledo. 2011. Dirigido por García y García, A. Madrid: Biblioteca de Autores cristianos. 
Synodicon Hispanum. XI - Cádiz, Canarias, Cartagena, Córdoba, Granada, Málaga y Sevilla. 2013. Dirigido por García y García, A. Madrid: Editorial Católica.

Talavera, H. d. 2012. Católica impugnación: del herético libelo maldito y descomulgado, que en el año pasado del nacimiento de nuestro Señor Jesucristo de mil y cuatrocientos y ochenta años fué divulgado en la ciudad. Ed. C. D. Pastore. [Córdoba]: Editorial Almuzara.

Tejada y Ramiro, J. 1851. Coleccion de canones y de todos los concilios de la Iglesia española. Madrid: Imp. de Jose Maria Alonso.
Teodoro, L. A. 2017. "La Place des Opuscules Pastoraux au Portugal du XVe Siècle. L'Exemple Cistercien de l'Explication des Dix Commandements de la Loi de Dieu». Bulletin du centre d'études médiévales d'Auxerre - BUCEMA 21 (1). https://doi.org/10.4000/ cem.14654

Teodoro, L. A. 2019. Guias dos costumes cristãos. Os primeiros opúsculos pastorais em língua portuguesa. São Paulo: Editora Unifesp.

Vidal Doval. 2010. "Predicación y persuasión: Vicente Ferrer en Castilla, 1411-1412». Revista de poética medieval 24: 225-243. 